\title{
Screening and Production of Lipase from a Thermo-halophilic Bacterial Isolate of Pria Laot Sabang 80 Isolated from Under Water Hot Spring
}

\section{Febriani, Nurul H. Ulwiyyah, Nurdin Saidi, and Teuku M. Iqbalsyah}

Biomolecules Application Research Group, Chemistry Department, Faculty of Mathematics and Natural Sciences, Universitas Syiah Kuala, Banda Aceh, Indonesia

\section{Abstract}

Lipase is an important class of industrial hydrolytic enzyme that is produced mainly by bacteria. The goal of this study was to screen and determine the optimum conditions for lipase production by a thermo-halophilic bacterium, named Pria Laot Sabang 80 (PLS 80), isolated from an underwater hot spring. Screening of lipase was conducted on agar media supplemented with olive oil and rodhamine B. PLS 80 exhibited lipase

Corresponding Author:

Febriani

febriani@unsyiah.ac.id

Received: 19 February 2019

Accepted: 5 March 2019

Published: 16 April 2019

Publishing services provided by

Knowledge

(c) Febriani et al. This article is distributed under the terms of the Creative Commons

Attribution License, which permits unrestricted use and redistribution provided that the original author and source are credited.

Selection and Peer-review unde the responsibility of the ICBSA Conference Committee. activity based on the formation of orange red fluorescence area around the colonies observed under UV light. The growth curve and lipase activity of the isolate was studied at various temperature, incubation time, $\mathrm{pH}$ and salt concentrations. The growth curve was measured by dry cell biomass and lipase activity using spectrophotometry method by $\mathrm{p}$-nitrophenyl palmitate as the substrate. The isolate showed the highest biomass production after 16 hours of fermentation at $70{ }^{\circ} \mathrm{C}, \mathrm{pH} 9$ and with an addition of 3 $\mathrm{M} \mathrm{NaCl}$. The highest activity of lipase was $24.3 \mathrm{U} / \mathrm{mL}$. This study shows that PLS 80 produced a thermo-halostable alkaline lipase.

Keywords: Thermostable, halostable, lipase, Pria Laot Sabang

\section{Introduction}

Extreme environment have been an interesting object for microbiological research to study the diversity of extremophilic microorganisms. The ability to grow in extreme conditions makes the microorganisms unique. Extremophiles are a group of microorganisms that can live and thrive in extreme ambient conditions such as high temperatures (60 to $110{ }^{\circ} \mathrm{C}$, thermophiles and hyperthermophiles), low temperature $\left(-2\right.$ to $15{ }^{\circ} \mathrm{C}$, psychrophiles), high salinity (2-5 M NaCl, halophiles), high acidity $(\mathrm{pH}<4$, acidophiles), high alkalinity ( $\mathrm{pH}>9$ alkaliphiles), high pressure (piezophiles), high radiation (radiophiles) and high metal content (metalophiles) [1, 2]. Habitats of extremophiles are diverse in nature, such as hydrothermal vents, geothermal are, hot spring, and compost $[3,4]$. In 
line with their unique adaptation mechanism, extremophiles have a great potential in producing novel primary and secondary metabolites with unique properties [2].

Lipase (triacylglycerol acylhydrolases (EC 3.1.1.3) are one of hydrolase enzymes used in many industries that catalyze the hydrolysis of triglyceride (with acyl chain lengths of $>$ 10 carbon atoms) into diacyl or monoacyl glyceride, glycerol and free fatty acid. Lipase is largely used in industries that produce detergent, additives (modification of taste/flavor), chemicals (synthetic ester), pharmaceuticals, cosmetics, oleo chemicals, fat processing, and wastewater treatment [5]. Novel lipases are still being explored and identified to find new enzymes with better catalytic activity and stability. Thermo-halophiles are the most probable microorganisms to produce the enzymes with better properties [6].

Indonesia is one of the most potential area in the world to source polyextremophiles. One of those places is Pria Laot area in Sabang, having known to have underwater fumaroles. Based on the environmental conditions, the region is a potential habitat for polyextremophiles. This study was to preliminarily screen, grow and produce thermohalostable lipase from one of bacterial strains isolated from the area. The results of the study may be used to further develop a novel lipase with unique properties for industrial uses.

\section{Materials and Methods}

\subsection{Regeneration of microorganism}

PLS 80 isolate was regenerated on a solid medium containing of $0.8 \%$ peptone $(\mathrm{w} / \mathrm{V})$, $0.4 \%$ yeast extract $(\mathrm{w} / \mathrm{v}), 0.2 \% \mathrm{NaCl}(\mathrm{w} / \mathrm{v}), 0.25 \%$ glucose $(\mathrm{w} / \mathrm{v})$ and $3 \%$ agar bacto $(\mathrm{w} / \mathrm{v})$. The medium was dissolved with seawater, which had been filtered using $0.4 \mu \mathrm{m}$ cellulose syringe, then sterilized using autoclave for 15 minutes at $121^{\circ} \mathrm{C}$. The isolate was inoculated on the medium using a spreader and incubated at $70{ }^{\circ} \mathrm{C}$ for 24 hours.

\subsection{Screening of lipase}

The capability of PLS 80 in producing lipase was determined by growing the isolate onto an agar medium containing olive oil and rodhamine at alkaline $\mathrm{pH}$ as described by Kouker and Jaeger [7]. Lipase production was monitored under UV light at $350 \mathrm{~nm}$. 


\subsection{Growth curve study}

To study the growth of PLS 80 and lipase production, the isolate was grown in a lipase production medium containing $0.2 \% \mathrm{NaCl}(\mathrm{w} / \mathrm{v}), 0.25 \%$ glucose $(\mathrm{w} / \mathrm{v}), 0.4 \%$ yeast extract $(\mathrm{w} / \mathrm{v})$, and $0.8 \%$ peptone $(\mathrm{b} / \mathrm{v})$, supplemented with $1 \%$ olive oil $(\mathrm{v} / \mathrm{v})$ and $0.5 \%$ tween 80 (v/v). The medium was adjusted to $\mathrm{pH} 9.0$ glycine- $\mathrm{NaOH}$ buffer and incubated at $70{ }^{\circ} \mathrm{C}$, $150 \mathrm{rpm}$ for $48 \mathrm{~h}$. The growth and lipase activity were measured in 2-hours intervals.

The growth of PLS 80 was monitored by measuring the biomass in the form of dry weight. The samples of known volume were initially centrifuged at $5000 \mathrm{rpm}$. The pellet was dried and weighed. The dry weight was calculated as the difference of the pellet weight before and after drying per sample volume.

\subsection{The effect of temperature, $\mathrm{pH}$ and salt concentration on lipase production}

Optimum temperature for lipase production was determined by incubating PLS 80 in the media at various temperature of 65,70 and $75{ }^{\circ} \mathrm{C}$. The media were incubated at the optimum incubation time as found in Section 2.3. The lipase activity was measured as described in Section 2.5.

Optimum $\mathrm{pH}$ for lipase production was determined by incubating PLS 80 in the media at five different $\mathrm{pH}$ values, i.e. 8.5, 9.0, 9.5, 10.0 and 10.5. The $\mathrm{pH}$ was adjusted by adding glycine- $\mathrm{NaOH}$ buffer. The media were incubated at optimum incubation time and temperature. The lipase activity was then measured.

To study the tolerance of PLS 80 to salt concentration for lipase production, the isolate was inoculated into media with different addition of salt $\mathrm{NaCl}$, i.e. 1, 2, 3, and $4 \mathrm{M}$. The media were incubated at the optimum incubation time, temperature and $\mathrm{pH}$ based on the results of the previous steps. The lipase activity was then measured.

\subsection{Determination of lipase activity}

Lipase activity was measure spectrophotometrically as described by Lee [8] with $p$ nitrophenyl palmitate as the substrate. The enzyme activity was measured by monitoring the change in absorbance at $405 \mathrm{~nm}$ that represents the amount of $\mathrm{p}$-nitrophenol (PNP) released as the result of the enzyme activity. One unit of lipase is defined as the amount 
of enzyme releasing $1 \mu \mathrm{mol}$ PNP per min under the assay conditions. Futhermore, lipase activity was determined by equation (1).

$$
\text { Activity }(\mathrm{U} / \mathrm{mL})=\frac{[p-\text { nitro fenol }] \mu \mathrm{mol}}{\mathrm{mL}} \times \frac{1}{\text { incubation time (minute) }} \times \text { dilution factor (1) }
$$

\section{Results}

\subsection{Screening of lipase}

The ability of PLS 80 to produce lipase was checked by cultivating it in a medium containing olive oil as the inducer. It was clearly apparent that PLS 80 produced fluorescent halos indicating its capability to produce lipase. The color was even brighter than that of the positive control (Fig. 1).

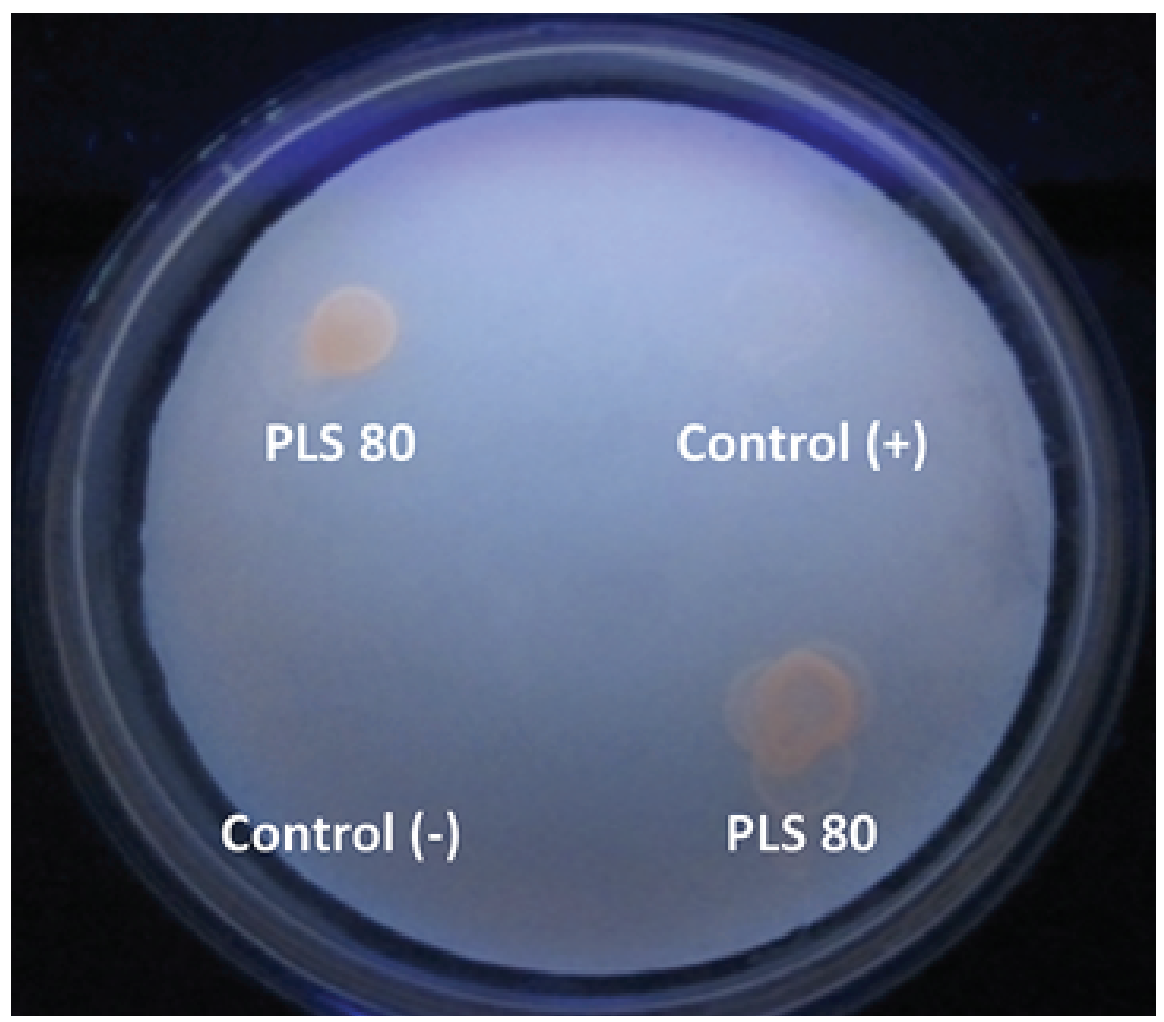

Figure 1: Screening of lipase activity from PLS 80 conducted on a medium containing olive oil and rodhamine at $\mathrm{pH} 9.0$ and monitored under UV light at $350 \mathrm{~nm}$.

\subsection{The growth of PLS 80}

Examining the growth and lipase production by PLS 80 is important to optimize the production parameters. Fig 2 shows that biomass and lipase production increased following the same trend. At the beginning of fermentation, the biomass was already high 
(nearly $3 \mathrm{mg} / \mathrm{mL}$ ). This could be due to the high concentration of inoculum added before the fermentation started. The biomass increased significantly and reached maximum at $14 \mathrm{~h}(3.9 \mathrm{mg} / \mathrm{mL})$. It decreased gradually afterwards and there was no obvious death phase seen up to $48 \mathrm{~h}$.

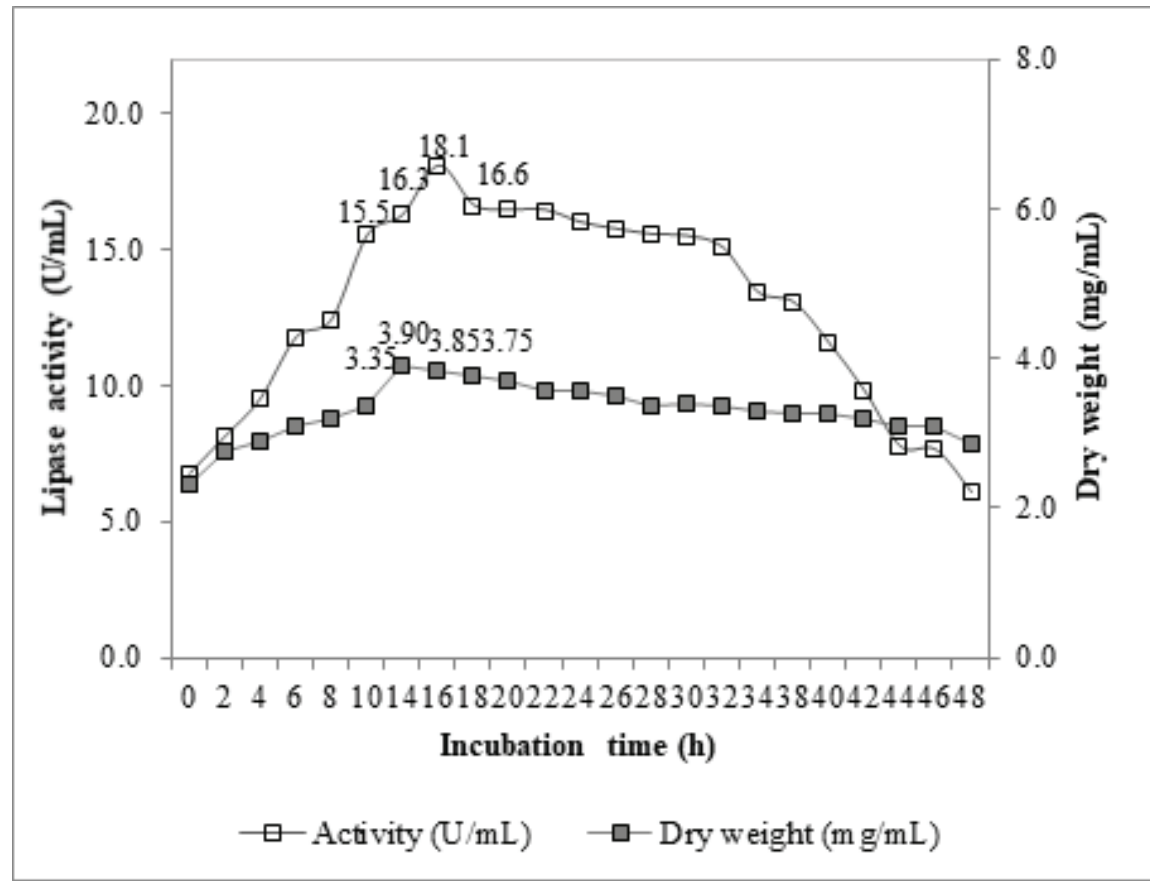

Figure 2: Dry weight and lipase activity of PLS 80 grown in a lipase production medium pH 9.0, incubated at $70{ }^{\circ} \mathrm{C}, 150 \mathrm{rpm}$ for $48 \mathrm{~h}$.

A similar trend was also observed for lipase activity, although the maximum was reached at a slightly delayed time. For similar reason as the biomass, the lipase activity was already high at the beginning $(6.8 \mathrm{U} / \mathrm{mL})$. The activity peaked at $16 \mathrm{~h}(18.1 \mathrm{U} / \mathrm{mL})$ and then decreased steadily up to $32 \mathrm{~h}$. The activity however dropped significantly in the later stage of fermentation.

\subsection{Effect of fermentation temperature on lipase production}

Determination of optimum temperature for lipase production was carried out at 60, 65 and $70^{\circ} \mathrm{C}$. The results were monitored between $14-20 \mathrm{~h}$ fermentation in $1 \mathrm{~h}$ interval. Fig. 3 shows that PLS 80 produced the highest lipase activity $(18.1 \mathrm{U} / \mathrm{mL})$ at $70{ }^{\circ} \mathrm{C}$ for $16 \mathrm{~h}$. Incubation at $65^{\circ} \mathrm{C}$ also produced the highest lipase activity at $16 \mathrm{~h}$, although the value was only about $85 \%$ of that at $70{ }^{\circ} \mathrm{C}(15.4 \mathrm{U} / \mathrm{mL})$. Meanwhile at $60{ }^{\circ} \mathrm{C}$, PLS 80 yielded the highest lipase activity $(14.8 \mathrm{U} / \mathrm{mL})$ at $19 \mathrm{~h}$. The activity was only $70 \%$ of that at $70{ }^{\circ} \mathrm{C}$. 


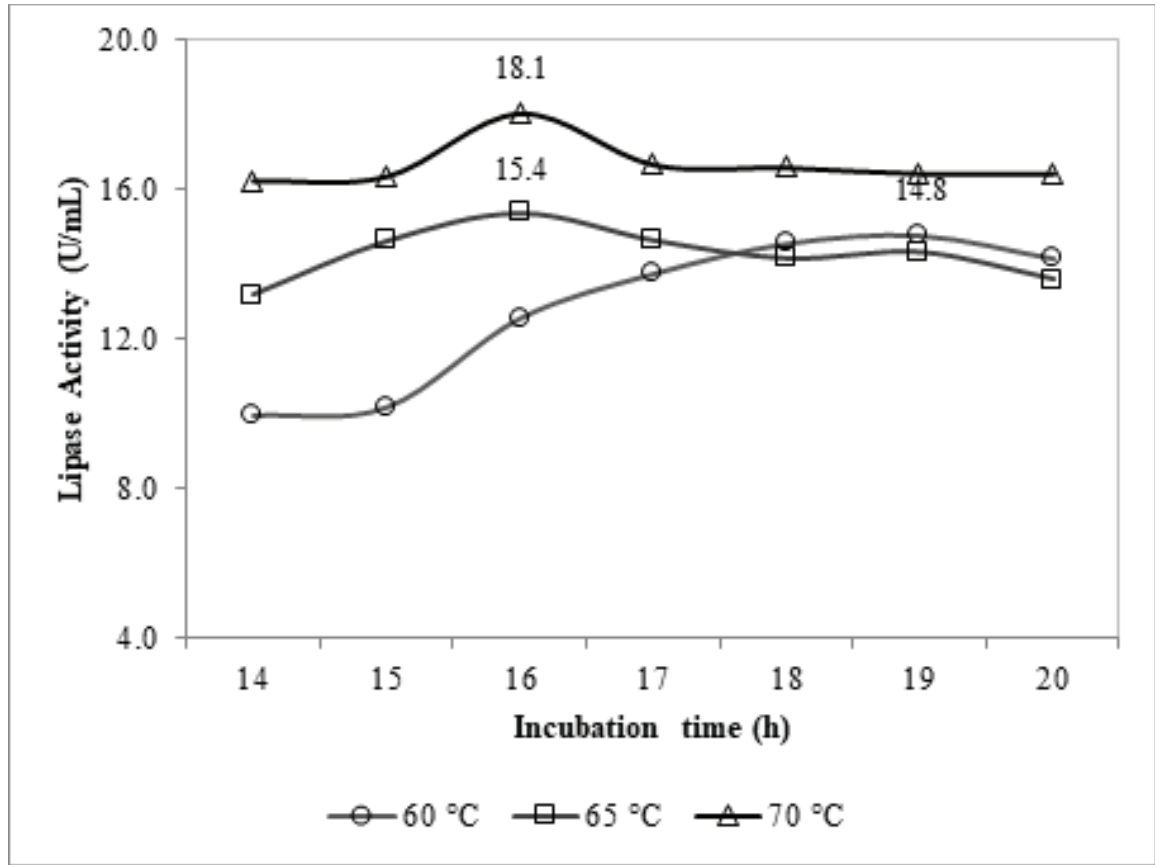

Figure 3: Activity of lipase from PLS 80 grown in media at various temperatures, $\mathrm{pH} 9.0$ incubated at 70 ${ }^{\circ} \mathrm{C}, 150 \mathrm{rpm}$ for $14-20 \mathrm{~h}$.

\subsection{Effect of pH on lipase production}

The effect of $\mathrm{pH}$ on lipase production was conducted by growing PLS 80 on media with various alkaline $\mathrm{pH}$ values $(8.5,9.0,9.5,10.0$ and 10.5$)$ at optimum temperature $\left(70{ }^{\circ} \mathrm{C}\right)$. The highest lipase activity was observed when PLS 80 was grown on slightly alkaline media. Medium with pH 9.0 produced the highest lipase activity $(19.7 \mathrm{U} / \mathrm{mL})$, a fraction higher than that at pH $8.5(19.0 \mathrm{U} / \mathrm{mL})$ (Fig. 4). The activity decreased considerably at higher $\mathrm{pH}$ values. The activity at $\mathrm{pH} 9.5$ was $15.5 \mathrm{U} / \mathrm{mL}$, which was about $80 \%$ of that at $\mathrm{pH}$ 9.0. Furthermore, the activities at $\mathrm{pH} 10.0$ and 10.5 were about half of that at $\mathrm{pH}$ 9.0.

\subsection{Effect of the addition of salt concentration on lipase production}

Determination of optimum salt concentration was carried out by growing PLS 80 on media with the addition of 1, 2, 3 and $4 \mathrm{M} \mathrm{NaCl}$. Fig 5 shows that the addition of 1 $\mathrm{M} \mathrm{NaCl}$ produced lipase with an activity of $19.8 \mathrm{U} / \mathrm{mL}$. The activity increased about $20 \%$ with the addition of $2 \mathrm{M} \mathrm{NaCl}(24.2 \mathrm{U} / \mathrm{mL})$ and $3 \mathrm{M} \mathrm{NaCl}(24.3 \mathrm{U} / \mathrm{mL})$. The activity decreased significantly $(15.0 \mathrm{U} / \mathrm{mL})$ when $4 \mathrm{M} \mathrm{NaCl}$ was added to the medium. 


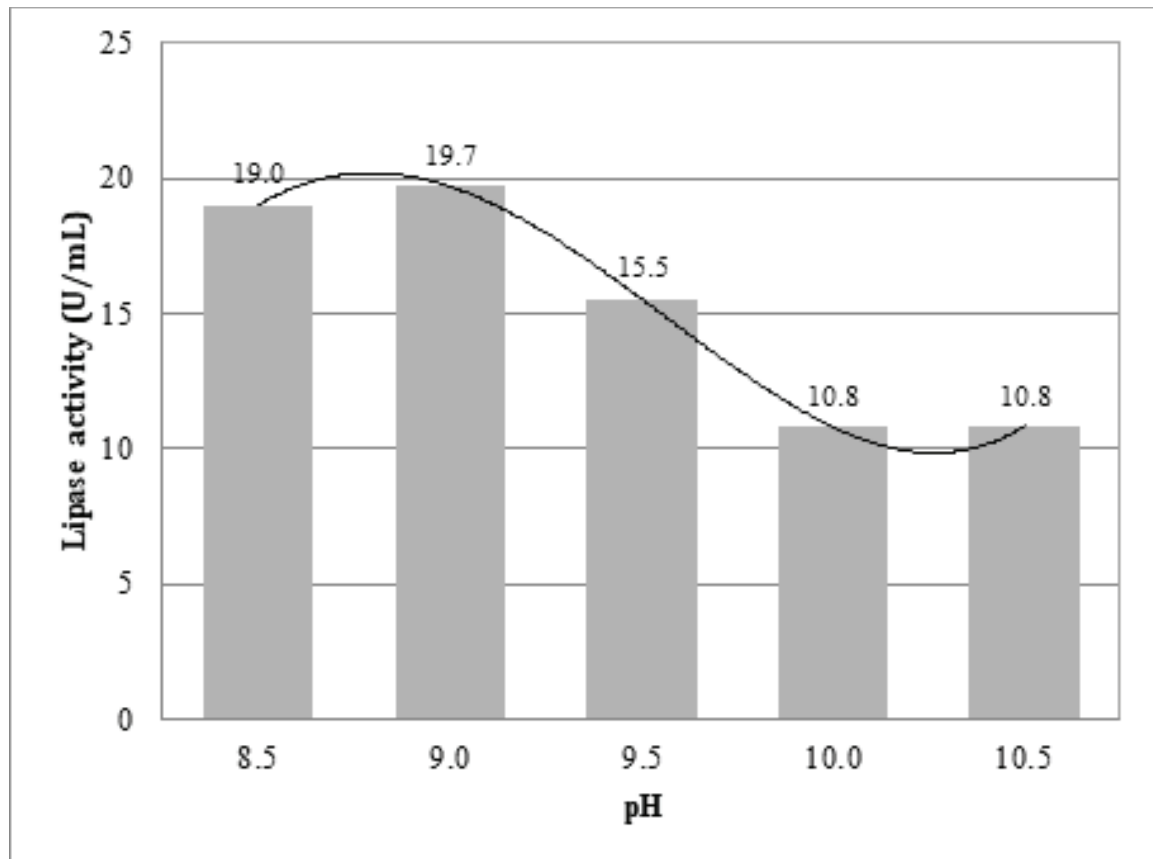

Figure 4: Activity of lipase from PLS 80 grown in media of various $\mathrm{pH}$, incubated at $70{ }^{\circ} \mathrm{C}, 150 \mathrm{rpm}$ for $16 \mathrm{~h}$.

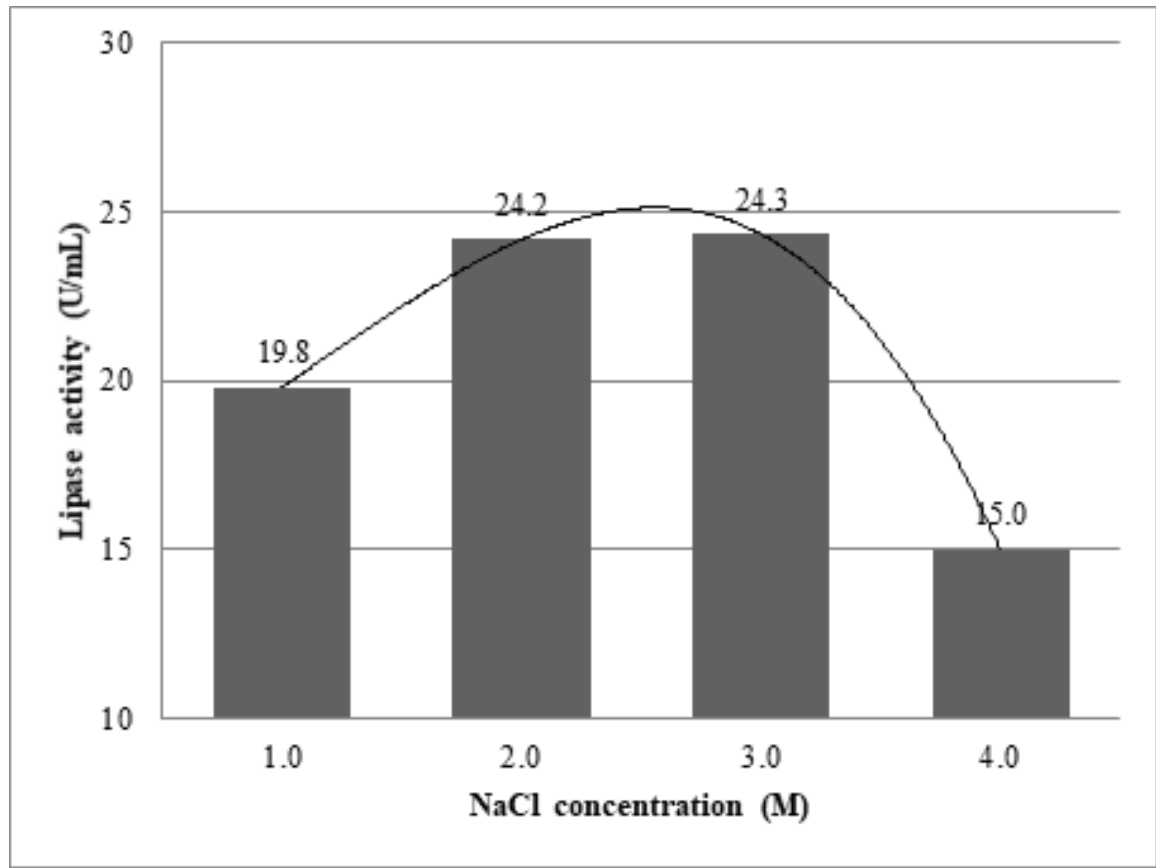

Figure 5: Activity of lipase from PLS 80 grown in media with the addition of various $\mathrm{NaCl}$ concentrations, $\mathrm{pH} 9.0$ incubated at $70{ }^{\circ} \mathrm{C}, 150 \mathrm{rpm}$ for $16 \mathrm{~h}$.

\section{Discussion}

The original isolation step of PLS 80 was done on $1 / 2$ Thermus minimum medium containing peptone, yeast extract, $\mathrm{NaCl}$, and agar. When using this medium, a prolong lag phase was experienced. The medium was then modified by incorporating a very 
low concentration of glucose to initiate growth. In order to produce extracellular lipase, olive oil was added to the medium as the inducer. The lack of significant amount of simple carbon source would force PLS 80 to utilize olive oil by secreting lipase, which hydrolyzes lipid to fatty acids and glycerol. Rhodamine B in the medium would then react with the released fatty acids, which produced an orange fluorescence color under UV light [7].

Lipase production is affected by the type and amount of carbon source, and nitrogen sources, $\mathrm{pH}$, temperature, as well as dissolved oxygen concentration in the media [9]. Several studies use olive oil to induce lipase secretion [10, 11]. Tween 80 is used to mediate water and lipid phases to be miscible. A mixture of peptone and yeast extract as the nitrogen sources in the medium has been reported to produce high level of lipase from Bacillus sp. and Pseudomonas sp [10].

Optimization of growth conditions (temperature, $\mathrm{pH}$ and salt content) is important because PLS 80 is a thermo-halophilic bacterium, isolated from under sea hot spring that may exhibit poly-extreme characters. The growth conditions thus significantly affect the lipase production and activity.

Optimum fermentation time for lipase production in this study is different than in other reports. Fermentation time of PLS 80 to produce the highest lipase activity is twice as long as that of Bacillus sp. RSJ-1, which shows an optimum at $7 \mathrm{~h}$ [12]. However, the activity is twice of that from Bacillus sp. RSJ-1 (10.2 U/mL). Meanwhile, the fermentation time is about half of that from Bacillus sp. DVL2, that produce lipase best at $36 \mathrm{~h}$ [13]. Nevertheless, the lipase activity of PLS 80 is only half of that from Bacillus sp. DVL2. The difference is mainly due to the type of microorganisms, media, and fermentation conditions. Fermentation time is closely related to the opportunity of microorganisms to utilize the nutritional components in the medium to secrete their primary and secondary metabolites [14]. Some metabolites, however, may inhibit growth and decrease activity.

The growth temperature is also an important factor for metabolites production and closely related to the native habitat of microorganisms [2]. However, they may produce metabolites as a response to environmental stresses. These conditions may vary from one species to another. Therefore PLS 80 is assumed to produce lipase with distinct characteristics.

In general, the optimum temperature for lipase production from thermophilic microorganisms is in the range of 50 to $80^{\circ} \mathrm{C}$ [15]. Temperature for lipase production in this study is higher than that reported for Geobacillus sp. ARM strain $\left(50^{\circ} \mathrm{C}\right)$, although the activity was only one-fourth [14]. Lipase by PLS 80 was better produced in a slightly 
alkaline condition. Higher $\mathrm{pH}$ reduced the lipase activity, which may due to the change in ionic interaction within the protein molecules.

It is anticipated that PLS 80 could produce lipase with the addition of reasonably high concentration of salt to the media. The growth media for PLS 80 was already made in sea water. In this study, the addition up to $3 \mathrm{M}$ sodium chloride increased the activity. The activity decreased when $4 \mathrm{M} \mathrm{NaCl}$ was added that might be due to the inability of PLS 80 to regulate osmotic pressure inside the cells. The enzymes structure in the cells might also denature, causing the lost in activity, thus slowing down the metabolic rate. Madern [16] reports that halophiles are able to live in environments with high salt content because of their ability to regulate osmotic equilibrium and counteract the effects of protein denaturation by salt. The results suggest that PLS 80 was a moderate halophilic microorganism.

\section{Conclusions}

PLS 80 was able to produce extracellular thermo-halostable alkaline lipase. Lipase production was optimal in alkaline media $\left(\mathrm{pH} \mathrm{9.0)}\right.$ at $70{ }^{\circ} \mathrm{C}$ for 16 hours. The lipase was a moderate halotolerant enzyme as its activity is high in the addition of $3.0 \mathrm{M} \mathrm{NaCl}$. Lipase with these characteristics may be used in detergent and biodiesel fields. Further studies are still needed, however.

\section{Acknowledgement}

The authors would like to thank the anonymous referees for their valuable suggestions, which led to the improvement of this article. This research was funded by PDUPT 34/UN11.2/PP//SP3/2018 Universitas Syiah Kuala, granted to Febriani.

\section{Conflict of Interest}

There is no conflict of interest.

\section{References}

[1] Bonch-Osmolovskaya, E., and Atomi, H. 2015. Editorial overview: Extremophiles: From extreme environments to highly stable biocatalysts. Curr. Opin. Microbiol. 25. p vii-viii 
[2] Kumar, L., Awasthi, G., and Singh, B. 2011. Extremophiles: A novel source of industrially important enzymes. Biotechnol. 10 (2): 121-135.

[3] Mohandass, C., Rajasabathy, R., Ravindran, C., Colaco, A., Santos, R., and Meena, R. M. 2012. Bacterial diversity and their adaptations in the shallow water castro seamount (DJCS), Azores, Portugal. Cah. Biol. Mar. 53: 65-76.

[4] Dalmaso, G.Z.L., Ferreira, D. and Vermelho, A.B. 2015. Marine extremophiles: A source of hydrolases for biotechnological applications. Mar. Drugs. 13: 1925-1965.

[5] Adrio, J.L. and Demain, A.L. 2014. Microbial enzyme: Tools for biotechnological processes. Biomolecules 4: 117-139.

[6] Jaeger,K.E., Dijkstra, B.W. dan Reetz, M.T. 1999. Bacterial biocatalysts: Molecular biology, three-dimensional structures, and biotechnology applications of lipases. Ann. Rev. Microbiol. 53: 315-351.

[7] Kauker, G. and Jaeger, K.E. 1987. Specific and sensitive plate assay for bacterial lipases. Appl. Env. Microbiol. 53 (1): 211-213.

[8] Lee, D., Koh, Y., Kim, K., Kim, B., Choi, H., Kim, D., Suhartono, M.T., and Pyu, Y. 1999. Isolation and characterization of a thermophilic lipase from Bacillus thermoleovorans ID1. FEMS Microbiol. Lett. 179: 393-400.

[9] Treichei H., Oliveira D., Mazutti M.A., Luccio M.D., Oliveira J.V., A. 2010. Review on microbial lipases production, Food Bioprocess Technol, 3: 182-196.

[10] Habibollahi, H., and Salehzadeh, A. 2018. Isolation, optimazation, and molecular characterization of a lipase producing bacterium from oil contaminated soils. Pollution, 4 (1): 119-128.

[11] Fadiloglu,S., and Erkmen, O. 2002. Effects of carbon and nitrogen sources on lipase production by Candida rugosa. Turkish.J.Eng.Env.Sci., 26 (10): 249-254.

[12] Sharma, R.C.Y., and Banerjeea. U.C. 2001. Production purification characterization and applications of lipases.Res. Review Paper. Biotechnol. Advance 19: 627-662.

[13] Davender, K., Lalit, K., Sushil, N., Raina, C., Rajinder, P. and Vijay, K. 2012. Screening, isolation and production of lipase/esterase producing Bacillus sp. strain DVL2 and its potential evaluation in esterification and resolution reactions. Arch. Appl. Sci. Res. 4 (4): $1763-1770$

[14] Ebrahimpour, A., Abd-Rahman, R. N. Z. R., Diana Hooi Ean Ch'ng, Basri, M. and Salleh, A. B. 2008. A modeling study by response surface methodology and artificial neural network on culture parameters optimization for thermostable lipase production from a newly isolated thermophilic Geobacillus sp. strain ARM. BMC Biotechnol. 8: 96. 
[15] Berekaa, M. M., Zaghloul, T. I., Abdel-Fattah, Y. R., Saeed, H. M., and Sifour, M. 2009. Production of a novel glycerol-inducible lipase from thermophilic Geobacillus stearothermophilus strain-5. World J. Microbiol. Biotechnol. 25: 287-294.

[16] Madern et al. 2000. Halophilic adaptation of enzymes. Extremophiles 4: 91-98. 